\title{
Implant-supported prostheses versus conventional permanent and removable dentures
}

\author{
Agnieszka Koszuta ${ }^{1}$, Jolanta Szymanska ${ }^{2 *}$
}

${ }^{1}$ Non-Public Healthcare Centre "Dental" in Tomaszow Mazowiecki, Poland

${ }^{2}$ Chair and Department of Paedodontics, Medical University of Lublin, Karmelicka 7, 20-081 Lublin, Poland

\section{ARTICLE INFO}

Received 13 February 2014

Accepted 03 March 2014

\section{Keywords:}

prosthetic replacements,

implant prosthetic treatment,

demographic factors.

\begin{abstract}
Social, economic and technological progress results in an increasing range of treatment and rehabilitation methods for patients with partial or complete edentulism. The role of the dentist is to inform the patient about the full range of available missing teeth treatment options leading to complete rehabilitation of the masticatory organ in agreement with the patient's aesthetic and functional expectations. The aim of the paper was to identify the type of prostheses used by patients before opting for implantsupported teeth replacements, according to the patients' age, sex, marital status, place of residence and education. The study covered 464 patients, women and men, aged 20-74, treated with dental implants. The patients answered questions in an anonymous questionnaire. The influence of the prosthetic replacement type according to age and marital status was highly statistically significant, whereas it was statistically significant according to sex, place of residence and education. The female respondents who previously used tissue-borne complete or partial dentures opted for implant treatment more frequently. The respondents younger than 40 and between $40-60$ years of age who did not previously used any prosthetic replacements opted for implant treatment more frequently. The respondents who did not use any prosthetic replacements decided to undergo implant treatment most frequently, regardless of their marital status, education and place of residence. The patients opted for implant treatment to improve their quality of life, despite the high cost of such therapy.
\end{abstract}

\section{INTRODUCTION}

Recent achievements in the field of medicine and dentistry have significantly changed attitudes to the problem of permanent teeth loss in patients at any age. Social, economic and technological progress results in an increasing range of treatment and rehabilitation methods for patients with partial or complete edentulism [7].

The needs of the Polish population in the area of conservative and prosthetic treatment are high to a large degree unsatisfied. The studies conducted in 2003 showed that over $50 \%$ of adults aged $35-44$ and $30 \%$ of those aged $67-74$ had untreated missing teeth. The average number of teeth in the oral cavity found in different age groups was, respectively: 35-44 years - 24.24 teeth; 45-64 years - 19.09 teeth; 65-74 years -12.50 teeth; and over 74 years -9.41 teeth [14]. The

Corresponding author

* e-mail: szymanska.lublin@gmail.com data provided by the programme "Oral Cavity Health Monitoring" indicate that in 2009 the percentage of edentulous Poles at the age $65-74$ reached $43.9 \%$ of the population, and the masticatory function was preserved only in $43.9 \%$ of this age group. In 2002, however, this proportion was $69.4 \%$, which points to a deteriorating dentition status [10]. The cited results confirm the fact that the challenge for dentists is enormous.

The role of the dentist is to inform the patient about the full range of available missing teeth treatment options leading to complete rehabilitation of the masticatory organ in agreement with the patient's aesthetic and functional expectations [3].

\section{AIM}

The aim of the paper was to identify the type of prostheses used by patients before opting for implant-supported teeth replacements, according to the patients' age, sex, marital status, place of residence and education. 


\section{MATERIAL AND METHODS}

The study covered 464 patients, women and men, aged 20-74, treated with prosthetic implants at the Non-Public Healthcare Centre "Dental" in Tomaszów Mazowiecki, Poland. The patients anonymously answered the questions concerning their sex, age, marital status, place of residence, education, and previously used prosthetic replacements.

The respondents were divided into groups according to their age: younger than 40 years $(n=157), 40-60$ years $(n=241)$, and over 60 years $(n=66)$; and according to their place of residence (village, small town - population 20,00050,000, large city - population 100,000-500,000).

Correlations between the variables were analyzed using $\chi^{2}$ independence test. Statistical analysis was performed with Statistica 6.0 (StatSoft, Inc., Tulsa, Oklahoma, USA).

\section{RESULTS}

The study showed that $48.7 \%$ of the respondents (226 patients) who opted for implant-based prosthetic replacements had not used any prosthetic treatment: the percentage of such patients was $50 \%$ of the men, and $47.37 \%$ of the women. The decision to have implant treatment was much more frequently taken by women who had used complete or partial tissue-borne dentures; in the case of men, such a decision was taken more frequently by the permanent replacement users (Table 1 ).

The respondents aged under 40 and between 40 and 60 years who did not use prosthetic replacements opted for implant treatment much more frequently than other patients, while those over 60 made this decision if they previously used partial tissue-borne dentures (Table 2).

Table. 1. Frequency of dental implant treatment according to sex and prosthetic replacement type used before the treatment

\begin{tabular}{|l|c|c|c|c|c|c|}
\hline \multirow{3}{*}{ Sex } & \multicolumn{7}{|c|}{ Prosthetic replacement } & \\
\cline { 2 - 7 } & $\begin{array}{c}\text { Complete } \\
\text { denture }\end{array}$ & $\begin{array}{c}\text { Tissue- } \\
\text { borne } \\
\text { partial } \\
\text { denture }\end{array}$ & $\begin{array}{c}\text { Removable } \\
\text { partial } \\
\text { denture }\end{array}$ & $\begin{array}{c}\text { Permanent } \\
\text { replacement(s) }\end{array}$ & $\begin{array}{c}\text { No } \\
\text { replacement }\end{array}$ & Total \\
\hline \multirow{2}{*}{ Men } & 11 & 25 & 37 & 45 & 118 & 236 \\
\cline { 2 - 8 } & $4.66 \%$ & $10.59 \%$ & $15.68 \%$ & $19.07 \%$ & $50.00 \%$ & $100 \%$ \\
\hline \multirow{2}{*}{ Women } & 21 & 33 & 20 & 46 & 108 & 228 \\
\cline { 2 - 7 } & $9.21 \%$ & $14.47 \%$ & $8.77 \%$ & $20.18 \%$ & $47.37 \%$ & $100 \%$ \\
\hline Total & 32 & 58 & 57 & 91 & 226 & 464 \\
\hline \multicolumn{7}{|c|}{ Test function value $\chi^{2}=9.617, \mathrm{p}=0.047$} \\
\hline
\end{tabular}

Table. 2. Frequency of dental implant treatment according to age and prosthetic replacement type used before the treatment

\begin{tabular}{|l|c|c|c|c|c|c|}
\hline \multirow{2}{*}{ Age } & \multicolumn{7}{|c|}{ Prosthetic replacement } & \multirow{2}{*}{$\begin{array}{c}\text { Complete } \\
\text { denture }\end{array}$} & $\begin{array}{c}\text { Tissue- } \\
\text { borne } \\
\text { partial } \\
\text { denture }\end{array}$ & $\begin{array}{c}\text { Removable } \\
\text { partial } \\
\text { denture }\end{array}$ & $\begin{array}{c}\text { Permanent } \\
\text { replacement(s) }\end{array}$ & $\begin{array}{c}\text { No } \\
\text { replacement }\end{array}$ & Total \\
\hline \multirow{2}{*}{$\begin{array}{l}\text { Younger } \\
\text { than } 40\end{array}$} & 3 & 13 & 6 & 21 & 114 & 157 \\
\cline { 2 - 7 } & $1.91 \%$ & $8.28 \%$ & $3.82 \%$ & $13.38 \%$ & $72.61 \%$ & $100 \%$ \\
\hline \multirow{2}{*}{$\begin{array}{l}\text { Between } \\
40 \text { and } 60\end{array}$} & 18 & 24 & 34 & 60 & 105 & 241 \\
\cline { 2 - 7 } $\begin{array}{l}\text { Older than } \\
60\end{array}$ & $11.47 \%$ & $9.96 \%$ & $14.11 \%$ & $24.90 \%$ & $43.57 \%$ & $100 \%$ \\
\cline { 2 - 7 } & $16.67 \%$ & $31.82 \%$ & $25.76 \%$ & $15.15 \%$ & $10.61 \%$ & $100 \%$ \\
\hline Total & 32 & 58 & 57 & 91 & 226 & 464 \\
\hline \multicolumn{7}{|c|}{ Test function value $\chi^{2}=102.567, p<0.001$} \\
\hline
\end{tabular}

Both single and married patients who did not use prosthetic replacements, as well as single previously married patients who used partial tissue-borne dentures, permanent dentures or had untreated missing teeth opted for implant treatment more often than other respondents (Table 3 ).

Table 3. Frequency of dental implant treatment according to marital status and prosthetic replacement type used before the treatment

\begin{tabular}{|l|c|c|c|c|c|c|}
\hline \multirow{4}{*}{$\begin{array}{c}\text { Marital } \\
\text { status }\end{array}$} & $\begin{array}{c}\text { Complete } \\
\text { denture }\end{array}$ & $\begin{array}{c}\text { Tissue- } \\
\text { borne } \\
\text { partial } \\
\text { denture }\end{array}$ & $\begin{array}{c}\text { Removable } \\
\text { partial } \\
\text { denture }\end{array}$ & $\begin{array}{c}\text { Permanent } \\
\text { replacement(s) }\end{array}$ & $\begin{array}{c}\text { No } \\
\text { replacement }\end{array}$ & Total \\
\hline \multirow{2}{*}{ Unmarried } & 0 & 2 & 12 & 4 & 54 & 72 \\
\cline { 2 - 7 } & $0.00 \%$ & $2.78 \%$ & $16.67 \%$ & $5.56 \%$ & $75.00 \%$ & $100 \%$ \\
\hline \multirow{2}{*}{ Married } & 26 & 41 & 41 & 70 & 154 & 332 \\
\cline { 2 - 7 } & $7.83 \%$ & $12.35 \%$ & $12.35 \%$ & $21.08 \%$ & $46.39 \%$ & $100 \%$ \\
\hline $\begin{array}{l}\text { Divorced/ } \\
\text { widow } \\
\text { (widower) }\end{array}$ & 6 & 15 & 4 & 17 & 18 & 60 \\
\cline { 2 - 7 } & $10.00 \%$ & $25.00 \%$ & $6.67 \%$ & $28.33 \%$ & $30.00 \%$ & $100 \%$ \\
\hline Total & 32 & 58 & 57 & 91 & 226 & 464 \\
\hline \multicolumn{7}{|c|}{ Test function value $\chi^{2}=50.954, p<0.001$} \\
\hline
\end{tabular}

The decision to have implant treatment was most frequently taken by the respondents who did not use prosthetic replacements, regardless of the place of residence; however, the majority of them were city residents. The patients from villages who used permanent replacements or partial tissue-borne dentures opted for implant treatment more often than other village residents. The patients who lived in small towns who used removable partial dentures or complete dentures decided to undergo implant treatment more frequently than others (Table 4).

Table 4. Frequency of dental implant treatment according to place of residence and prosthetic replacement type used before the treatment

\begin{tabular}{|c|c|c|c|c|c|c|}
\hline \multirow[b]{2}{*}{$\begin{array}{l}\text { Place of } \\
\text { residence }\end{array}$} & \multicolumn{5}{|c|}{ Prosthetic replacement } & \multirow[b]{2}{*}{ Total } \\
\hline & $\begin{array}{c}\text { Complete } \\
\text { denture }\end{array}$ & $\begin{array}{l}\text { Tissue- } \\
\text { borne } \\
\text { partial } \\
\text { denture }\end{array}$ & $\begin{array}{c}\text { Removable } \\
\text { partial } \\
\text { denture }\end{array}$ & $\begin{array}{c}\text { Permanent } \\
\text { replacement(s) }\end{array}$ & $\begin{array}{c}\text { No } \\
\text { replacement }\end{array}$ & \\
\hline \multirow{2}{*}{ Village } & 7 & 19 & 4 & 27 & 53 & 110 \\
\hline & $6.36 \%$ & $17.27 \%$ & $3.64 \%$ & $24.55 \%$ & $48.18 \%$ & $100 \%$ \\
\hline \multirow{2}{*}{ Small town } & 21 & 31 & 37 & 37 & 105 & 231 \\
\hline & $9.09 \%$ & $13.42 \%$ & $16.02 \%$ & $16.02 \%$ & $45.45 \%$ & $100 \%$ \\
\hline \multirow{2}{*}{ City } & 4 & 8 & 16 & 27 & 68 & 123 \\
\hline & $3.25 \%$ & $6.50 \%$ & $13.01 \%$ & $21.95 \%$ & $55.28 \%$ & $100 \%$ \\
\hline Total & 32 & 58 & 57 & 91 & 226 & 464 \\
\hline
\end{tabular}

Table 5. Frequency of dental implant treatment according to education and the prosthetic replacement type used before the treatment

\begin{tabular}{|c|c|c|c|c|c|c|}
\hline \multirow[b]{2}{*}{ Education } & \multicolumn{5}{|c|}{ Prosthetic replacement } & \multirow[b]{2}{*}{ Total } \\
\hline & $\begin{array}{c}\text { Complete } \\
\text { denture }\end{array}$ & $\begin{array}{l}\text { Tissue- } \\
\text { borne } \\
\text { partial } \\
\text { denture } \\
\end{array}$ & $\begin{array}{c}\text { Removable } \\
\text { partial } \\
\text { denture }\end{array}$ & $\begin{array}{c}\text { Permanent } \\
\text { replacement(s) }\end{array}$ & $\begin{array}{c}\text { No } \\
\text { replacement }\end{array}$ & \\
\hline \multirow{2}{*}{ Vocational } & 7 & 6 & 2 & 5 & 14 & 34 \\
\hline & $20.59 \%$ & $17.65 \%$ & $5.88 \%$ & $14.71 \%$ & $41.18 \%$ & $100 \%$ \\
\hline \multirow{2}{*}{ Secondary } & 15 & 11 & 15 & 25 & 66 & 132 \\
\hline & $11.36 \%$ & $8.33 \%$ & $11.36 \%$ & $18.94 \%$ & $50.00 \%$ & $100 \%$ \\
\hline \multirow{2}{*}{ University } & 10 & 41 & 40 & 61 & 146 & 298 \\
\hline & $3.36 \%$ & $13.76 \%$ & $13.42 \%$ & $20.47 \%$ & $48.99 \%$ & $100 \%$ \\
\hline Total & 32 & 58 & 57 & 91 & 226 & 464 \\
\hline
\end{tabular}


The respondents who did not use prosthetic replacements opted for implant treatment regardless of their education. The patients with vocational education who used permanent dentures decided to have implant treatment more frequently, while among the patients with secondary and university education, such a decision was taken by those using permanent replacements (Table 5).

\section{DISCUSSION}

Our study shows that among the female respondents, the decision to have implant treatment was taken most frequently by the patients who had previously used tissue-borne partial or complete dentures. As it is known, tissue-borne partial dentures have undesirable effects, cause chronic gingivitis, exposure of dental necks, and damage both to the soft tissues and bones [12]. In addition, improper stabilization of a tissue-borne denture in the oral cavity may result in speech and eating problems, anxiety about a possible "falling out" of the prosthesis, leading to aversion to wear such replacements and, to some extent, to a psychosocial handicap $[1,5,11]$.

Among the male respondents, the patients who used permanent replacements opted for implant treatment most frequently. A permanent prosthetic replacement, if it is correctly designed and executed at both clinical and laboratory stage, may be successfully used by the patient. However, the fabrication of such replacements may also lead to complications that result from the necessity to considerably cut abutment teeth, causing injury to their pulp and also possibly damaging the periodontium during cutting [8]. The fabricated crown must eventually adhere precisely to the abutment tooth at the correct distance from the periodontium. Otherwise, the gums and surrounding tissues are continually irritated, which leads to inflammation and atrophic changes. The exposure of the crown edge causes considerable aesthetic problems [9].

The use of prosthetic of conventional, either removable or permanent, does not entirely satisfy the patients. It does not fully reproduce the masticatory function and the required aesthetics. For these reasons, the patients choose the replacements based on prosthetic implant, which enables an effective restoration of the masticatory function and aesthetics even in difficult anatomical conditions [13]. It also does not require the preparation of the patient's own teeth $[7,8]$.

As the study results show, the type of previously used prosthetic replacements affected the decision to undergo implant treatment. The respondents below 60 years opted for such treatment significantly more frequently if they had not previously used any prosthetic replacements to restore functionality of the masticatory organ and increase their psychological comfort. The patients who used tissue-borne partial dentures opted for implant treatment more frequently at the age of over 60 years, which may have resulted from their need to replace their prostheses with new ones that would be more durable and comfortable. Intraosseous implants may be used as abutments for permanent replacements, but also to stabilize removable prostheses [6]. According to Knychalska-Karwan, an interest in the improvement of one's appearance and of mouth functionality may be observed to increase steadily also among elderly patients [4].

According to the results obtained in our study, the decision to undergo dental implantation was most frequently taken by both unmarried and married patients who had not previously used any replacement, as well as by singlepreviously married respondents who had used tissue-borne dentures, permanent dentures, or no prosthetic replacement. Also, the respondents who did not use any replacements opted for intraosseous implants more frequently than others, regardless of the place of residence. Similarly, the decision to undergo implant treatment was taken more frequently by the patients who had not used any prosthetic replacement and did not depend on their education. Among the remaining respondents, the majority of the patients with vocational education used removable dentures before implantation, while among the patients with secondary and university education the majority used permanent replacements. This may be related to a greater self-confidence of people with complete dentition in human contacts. Missing teeth replacement improves psychological and physical welfare of patients [2]. Replacing missing teeth, it is extremely important to adopt treatment and rehabilitation procedures that correspond to the patient's expectations [11].

The treatment of partially or completely edentulous patients enables, on the one hand, the restoration of masticatory organ function, which improves their physical condition. On the other hand, it significantly improves the patient's psychological welfare. Teeth loss often causes a decrease in self-esteem, an aversion to contacts with other people, lack of self-confidence and stress. Replacing missing teeth in the way that guarantees the greatest possible satisfaction of the patient enables her or him to engage in normal family life and professional activities $[2,11]$.

Permanent replacements based on implanted abutments do not require preparation by cutting the patient's own teeth. Intraosseous implants used to stabilize removable prostheses guarantee their best possible stability in the oral cavity. They also enable the use of permanent replacements in the case of shortened dental arches. The use of implants makes it possible to improve aesthetics, masticatory organ functionality and the quality of speech. This enables the patients' unlimited functioning in society, improves their self-esteem and satisfaction with life $[11,15]$.

\section{CONCLUSIONS}

1. The female respondents who previously used tissue-borne complete or partial dentures opted for implant treatment more frequently.

2. The respondents younger than 40 and between 40-60 years of age who did not previously used any prosthetic replacements opted for implant treatment more frequently.

3 . The respondents who did not use any prosthetic replacements decided to undergo implant treatment most frequently, regardless of their marital status, education and place of residence.

4. The patients opted for implant treatment to improve their quality of life, despite the high cost of such therapy. 


\section{REFERENCES}

1. Burzyńska B., Mierzwińska-Nastalska E.: Rehabilitacja protetyczna pacjentów bezzębnych. Nowa Stomatologia, 4, 167, 2011.

2. Cieślak A., Trykowski J.: Wpływ stanu ruchomych protez zębowych oraz leczenia protetycznego na zdrowie pacjenta. Stomat. Wspót., 17, 25, 2010.

3. Czajkowska A. et al.: Czynniki wpływające na przebieg leczenia i adaptację do protez - przegląd piśmiennictwa. e-Dentico, 41, 70, 2013.

4. Knychalska-Karwan Z.: Pacjent geriatryczny w gabinecie stomatologicznym. Mag. Stomatol., 14, 7, 2004.

5. Koczorowski R.: Rekonstrukcja zgryzu za pomocą stałych implantoprotez zębowych. Stomat. Współ., 16, 44, 2009.

6. Koczorowski R., Bielińska M., Pieńkowska K.: Niektóre wykładniki oceny terapii implantoprotetycznej. Stomat. Wspót., 18, 31, 2011.

7. Koczorowski R., Gałczyńska-Rusin M., Koczorowski J.: Rekonstrukcja zwarcia z zastosowaniem stałych implantoprotez u osób starszych. Protet. Stomatol., 60, 94, 2010.

8. Kopczyński P., Matthews-Brzozowska T., Flieger R.: Odbudowa implantoprotetyczna w przypadku wąskiego wyrostka zębodołowego. Mag. Stomatol., 7-8, 60, 2012.
9. Mańkowska M., Fedorowicz E., Trykowski J.: Jatrogenne aspekty wpływu wykonywanych zabiegów oraz konstrukcji stałych uzupełnień protetycznych na przyzębie. Stomat. Wspót., 18, 50, 2011.

10. Porębska H., Lella A.: “Szczerbaty ekran”. Gazeta Lekarska, 8-9, $20,2010$.

11. Schlegel-Zawadzka M., Wójcikowska A.: Jakość życia człowieka dorosłego z uzupełnieniem protetycznym. Stomatol. Współ., 20, $26,2013$.

12. Spiechowicz M.: Protetyka stomatologiczna. ed. PZWL, Warszawa 2008.

13. Szymańska J., Koszuta A.: The level of patient satisfaction with implant treatment of missing teeth. Curr. Iss. Pharm. Med. Sci., 25, 243, 2012.

14. Wochna-Sobańska M., Borysewicz-Lewicka M.: Stomatologiczne potrzeby lecznicze ludności Polski w świetle epidemiologicznych badań wykonanych w 2003 roku w ramach programu "Miesiąc totalnie zdrowego uśmiechu”. Czas. Stomatol., 60, 299, 2007.

15. Ziołecka B.: Jakość życia związana ze zdrowiem (HRQoL) w aspekcie rehabilitacji narządu żucia. Dental Forum, 39, 69, 2011. 